Bangladesh Journal of Medical Science Vol. 11 No. 03 July’12

$\underline{\text { Review Article }}$

\title{
A review of some Antiretroviral therapies used in Management of HIV/AIDS in Ghana \\ Osonuga $\mathrm{A}^{1}$, Osonuga $\mathrm{OA}^{2}$, Osonuga $\mathrm{AA}^{3}$, Osonuga $\mathrm{IO}^{4}$
}

\begin{abstract}
$\underline{\text { Abstract }}$
HIV is a RNA retrovirus that causes progressive weakening of the host's immune system increasing susceptibility to opportunistic infections. Antiretroviral drugs are currently used to manage the infection. This paper reviews the benefits and the toxicity associated with ARTs currently used in Ghana. Google search, PUBMED and Google scholar were used to gather information from different books, websites and peerreviewed journal articles. ARTs significantly improved the quality of life of people living with HIV/AIDS by increasing the CD4 count and reducing the viral load. ARTs have short and long term side effects which may be life threatening. Toxicity may vary from drug to drug and from one drug class to the other. We conclude that it is important to select a regimen that is not only effective but also safe. This requires consideration of not only the toxicity potential of an ARV regimen but also an individual patient's underlying conditions, concomitant medications and history of drug intolerance.
\end{abstract}

\section{Introduction}

The Human Immunodeficiency Virus (HIV) is a lentiretrovirus with a complex genome. It causes progressive weakening of the host's immune system increasing susceptibility to opportunistic infections. The complication of HIV infection is Acquired immunodeficiency syndrome (AIDS) and death if unmanaged. Two types of the virus have been identified; HIV-1 which is the primary cause of AIDS world wide and HIV-2, found mostly in West Africa. It presently has no cure ${ }^{1,2}$.

In 2009, HIV epidemic affects about ${ }^{33.3}$ million people with most cases (about 30 million) in developing countries especially in sub-Saharan Africa (SSA). In 2010, 9 million Cases of HIV infection required antiretroviral therapy but only over 6 million were able to access treatment in SSA. ${ }^{3,4}$

ART used in HIV infection include Fusion inhibitors (FI), Protease inhibitors (PIs) Nucleoside reverse transcriptase inhibitors (NRTIs), Non-nucleoside reverse transcriptase inhibitors (NNRTI) and Integrase inhibitors ${ }^{6}$

Currently, the World health organization (WHO) recommends multiple-drug combination therapy for treatment of HIV disease known as highly active retroviral therapy (HAART) ${ }^{7}$. It includes a combination of at least three retroviral drugs into a fixed dose.

HAART has improved the quality of life of people living with HIV infection and has also significantly reduced mortality, morbidity from HIV co-infections and viral transmission rates. ${ }^{1,5,7,8}$.

Despite the laudable achievements of HAART in combating HIV infection, like other drugs, they posses toxicities which could be life threatening.

This paper attempts to look into some common antiretroviral drugs in use (with emphasis on those available in Ghana) as approved by the WHO, their mechanisms of action, clinical use (benefits) and potential side effects.

\section{The HIV infection}

The first case of HIV infection in Ghana was recorded in 1986. HIV -1 infection accounts for $95.9 \%$ of infection, HIV -2 and co-infection of HIV 1 and 2

1. Osonuga A, School of Medical Sciences, University of Cape Coast, Ghana.

2. Osonuga OA,Departments of Pharmacology and Physiology, Olabisi Onabanjo University, Remo-Campus, Nigeria.

3. Osonuga AA, Department of Nursing, University of Cape Coast, Ghana

4. Osonuga IO, Departments of Pharmacology and Physiology, Olabisi Onabanjo University, Remo-Campus, Nigeria.

*Corresponds to: Osonuga Ayokunle, School of Medical Sciences, University of Cape Coast, Ghana. Email: overcomers2007@yahoo.com 
A review of some Antiretroviral therapies used in Management of HIV/AIDS in Ghana

accounting for $1.5 \%$ and $2.6 \%$ respectively ${ }^{9}$

$\mathrm{HIV}$ is transmitted through contact with infected body fluids (e.g. semen and whole blood), infected sharp objects (as used in circumcision and scarification), and mother - child transmission (15\%). Sexual intercourse is the most common primary route of infection (about 75 - 80\%). Women are however at higher risk of infection because of the vagina serves as the reservoir for infected semen. HIV carries the most serious social stigma among the sexually transmitted viral infections. ${ }^{9,10}$

Numerous co-infections have been associated with HIV infection. Hepatitis B and C co-infection with HIV is thought to be due to similar routes of transmission of the infections. It is associated with more rapid progression of viral hepatitis-related liver disease (e.g. cirrhosis, hepatocellular carcinoma, and fatal hepatic failure) ${ }^{7,8}$

HIV infection significantly increases the risk of active pulmonary tuberculosis by immunosupression 2. Other co-infections include opportunistic viral, bacterial, parasitic and fungal infections, HIV-associated nephropathy, cardiovascular diseases (which account for $10 \%$ of HIV related mortality) and diabetes mellitus. ${ }^{7}$

\section{The HIV replication cycle}

The HIV virus has a short replication cycle of about 1.5days. The HIV virus enters the host cells by attaching to the cell membrane's cluster of differentiation antigen 4 cell (CD4) receptor by viral membrane glycoprotein 120 (gp 120). Attachment is aided by CCR5 co-receptor of T-lymphocytes and CXCR4 co-receptors on macrophages. Upon penetration and uncoating, there is rapid replication of the virus involving the use of a reverse transcriptase to make a double stranded viral DNA that is incorporated into the host cell's DNA (in the nucleus) using the enzyme integrase. The host cell transcribes viral mRNA which is translated into early and late phase proteins, makes more copies of viral RNA which are assembled in the cytoplasm into virions. The virons mature by cleaving large polyproteins into smaller proteins by viral proteases and are surrounded by an envelope derived from the host cell membrane. ${ }^{10,11}$

HIV establishes latency in the nucleus of infected cells, usually not causing lysis, churning out millions of infective viral particles that infect other host cells. Its rapid replication cycle and mutation rate (due to lack of proofreading enzymes, leading to high genetic variability) make it very difficult to develop an effective vaccine 11 . Our present hope of HIV treatment is ART.

Classification of Antiretroviral therapy (ART)

The stages of the replication cycle of HIV are potential points for viral inhibition and hence form basis for ART classification. ${ }^{6,12}$

\section{Fusion or Entry Inhibitors:}

They relatively new class of antiretroviral agents first approved in 2003 for treating HIV infection. They prevent the entry of the HIV into human immune cells. Enfuvirtide is the first representative. It binds to the gp41 subunit of the viral envelope protein and prevents the conformational change required for fusion of viral and host's cell membrane. ${ }^{12}$

\section{Nucleoside/Nucleotide Reverse Transcriptase Inhibitors (NRTIS)}

They were first approved in 1987. Zidovudine was the first agent to be developed in this class. Others include abacavir,didanosine, stavudine, lamivudine, tenofovir. They are phosphorylated by intracytoplasmically by cellular enzymes to active forms which competitive inhibit HIV reverse transcriptase (see fig 1 above). They could also be incorporated into the growing viral DNA chain and cause chain termination. 6,8,12,13 $^{2}$

ZIDOVUDINE (3'-azido-3'-deoxythymidine, AZT): Available in Ghana as Combivir (with Lamivudine) administered orally as one tablet twice daily 9 . It is the first known antiretroviral drug and the commonest in SSA 8. It is a thymidine analogue administered at an adult dose of $300 \mathrm{mg}$. Following oral administration, Zidovudine is rapidly absorbed and extensively distributed. Binding to plasma protein is low. Zidovudine is eliminated primarily by hepatic metabolism hence dosage needs to be adjusted in hepatic failure.

Intracellularly, Zidovudine is phosphorylated to its active 5'-triphosphate metabolite, Zidovudine triphosphate (ZDV-TP). The principal mode of action of ZDV-TP is inhibition of RT via DNA chain termination after incorporation of the nucleotide analogue. AZT reduces viral transmission rates (especially to women with HIV RNA $<1,000$ copies $/ \mathrm{mL}$ ) when administered early in pregnancy to prevent mother-child transmission and prophylaxis 
for high risk health workers etc.

Toxic effects include severe anaemia, gastrointestinal disturbance (e.g. diarrhea, vomiting and flatulence), lactic acidosis, lipodystrophy, neutropenia, gonadotoxicity. 1,3,12,14

\section{LAMIVUDINE (2',3'-dideoxy, 3'-thiacytidine, 3TC):}

It was originally used to treat hepatitis B infection. It is administered at an adult dose of $150 \mathrm{mg}$, twice daily. Following oral administration, Lamivudine is rapidly absorbed and extensively distributed. It is mostly excreted in urine unchanged. It possesses fewer toxic effects. However rare cases of neutropenia have been documented..$^{3,12,15}$

\section{Non-Nucleoside Reverse Transcriptase Inhibitors (NNRTIS)}

They were approved for use in 1996. They bind directly to HIV -1 reverse transcriptase resulting in blockage of RNA and DNA-dependent DNA polymerase. The binding site is distinct from that of NRTIs. They require no phosphorylation and are not incorporated into the growing viral DNA chain. Delavirdine, efavirez (used in treatment of HIV/TB co-infection in Ghana) 2, nevirapine, rilpivirine are examples.

\section{Nevirapine}

It was approved for use in 1996. It is effective against HIV-1 but not HIV-2 infections. This is because the allosteric site of the virus has a different structure that nevirapine (and other NNRTIs) cannot bind to. It is administered orally at an adult dose of $200 \mathrm{mg}$. Metabolized is by the liver's CYP450 system and excreted in feces (10\%) and also urine (80\%).

It is endorsed by the WHO as prophylaxis in many developing world settings (including Ghana) as a cost-effective way of reducing mother-to-child transmission.

Life threatening hepatotoxicity is the major toxic effect of this drug. However unlike other hepatotoxic ARTs, nevirapine's toxicity increases with a higher patient CD4 count. Others include rashes and Steven Johnson's syndrome ${ }^{7,12,15}$

\section{PROTEASE INHIBITORS (PIs)}

Approved for use in 1995; they inhibit the maturation of the newly formed virus by inhibiting the pro- tease responsible for cleaving precursor molecules (polyproteins) into mature structural proteins, giving rise to immature and noninfectious viral particles. Examples include indinavir, saquinavir, rotinavir. ${ }^{7,12}$

Integrase Inhibitors Or Intergrase Standard Transfer Inhibitors (INSTIS):

They are the newest class of drugs and were approved for HIV treatment in 2007. They interfere with the integrase enzyme, which HIV needs to insert its genetic material into human cells. Zintevir is an example. ${ }^{6}$

CCR5 antagonists e.g. Maraviroc, maturation inhibitors e.g. alpha interferon are also in use ${ }^{7}$.

Currently, WHO suggests the use of ART for all people living with HIV (PLHIV) with a CD4 count of $=350$ cells $/ \mathrm{mm} 3$ and for those with WHO clinical stage 3 or 4 (if CD4 testing is not available). ${ }^{7}$

\section{The cost of ARTs in Ghana}

Initially ARTs cost $\$$ US 10,000 - $\$ 15,000$ per person per year. This was too expensive for most patients in the developing countries, including sub-Saharan Africa - the worst hit area with the HIV epidemic 1. The availability of cheap ARTs -was made possible by the UNITAID's focused programmes (in conjunction with pharmaceutical companies) and subsidy by government. ${ }^{8,9,14,16}$

In Ghana, the subsidized ARTs are Combivir (a combination of Zidovudine and Lamivudine), Viracept (Nelfinavir) and Nevirapine (free for pregnant women). Combivir and Viracept cost \$US 124-200 and $\$ 282$ respectivley. ${ }^{8,9}$

The most widely used drug combination $(\mathrm{d} 4 \mathrm{~T}+3 \mathrm{TC}+\mathrm{NVP})$ is available for \$US 52-64 per person per year. However, WHO recommends that countries phase out its use due its severe side effects usually attributed to stavudine (d4T) but it is still a widely used ART in children. ${ }^{8,14}$

\section{Highly active antiretroviral therapy (HAART)}

They were introduced in 1996. It involves three or four antiretroviral drugs combined into a single dose containing two NRTI plus one active drug from other ART classes usually NNRTI, PI (usually boosted with ritonivir, RTV), INSTI or a CCR5 antagonist. The preferred HAART in Ghana includes a 
A review of some Antiretroviral therapies used in Management of HIV/AIDS in Ghana

combination of $\mathrm{AZT}+3 \mathrm{TC}+\mathrm{NVP}$ as first line regimen ${ }^{8.13 .}$

\section{Materials and Methods}

Google search, PUBMED and Google scholar were used to gather information from different books, websites and peer-reviewed journal articles.
Results

ART significantly reduced morbidity and mortality rates (by $30-80 \%$ ), reduced viral load in most subjects, increased CD4 count, reduced transmission rates ${ }^{7,8,24,25}$ (table I).

Common toxicities were lipodystrophy, lactic acidosis, hepatotoxicity, hematotoxicity and osteotoxicity 23-31 (table II).

Table 1: Effects of ART on HIV infection

\begin{tabular}{|c|c|c|}
\hline $\begin{array}{l}\text { Evaluated } \\
\text { parameter }\end{array}$ & Effect of ART & Comments \\
\hline $\begin{array}{l}\text { Morbidity } \\
\text { and Mortality } \\
\text { rates }\end{array}$ & $\begin{array}{l}\text { Avertion of } 2.5 \text { million deaths globally (since 1995), } \\
1.8 \text { million, from sub-Saharan Africa }{ }^{8} \text {. } \\
\text { Improved survival, delayed progression and reduced } \\
\text { AIDS-related complications in patients with } \\
\text { advanced HIV disease. } \\
\text { Preserved renal function in patients with HIV- } \\
\text { associated neuropathy }{ }^{17} \text {, may attenuate liver disease } \\
\text { progression in persons coinfected with HBV and/or } \\
\text { HCV, reduced cardiovascular risk when (ART is } \\
\text { started early) }{ }^{7,19} \text {, reduce the risk of both HIV related, } \\
\text { AIDS and non-AIDS-defining malignancies }{ }^{7} \text {. } \\
\text { decline in the incidence of HIV associated dementia } \\
\text { from } 6.49 \text { per } 1,000 \text { person-years (before } 1997 \text { ) to } \\
0.66 \text { per } 1,000 \text { person-years (2003-2006) }{ }^{7}\end{array}$ & $\begin{array}{l}\text { The presence of chronic viral } \\
\text { hepatitis increases the risk of } \\
\text { ARV-induced liver injury; } \\
\text { however, majority of coinfected } \\
\text { persons do not develop clinically } \\
\text { significant liver injury } 7,18 \\
\text { Some studies showed higher } \\
\text { cardiovascular risk }{ }^{20,21} \text { especially } \\
\text { with treatment interruption }{ }^{22} \text {. }\end{array}$ \\
\hline $\begin{array}{l}\text { Viral } \\
\text { transmission } \\
\text { rate }\end{array}$ & $\begin{array}{l}\text { Significant reduction in perinatal transmission } \\
(20 \%-30 \% \text { to }<2 \% \text { in the United states). } \\
\text { Statistically significant decline in HIV prevalence } \\
\text { among pregnant women attending antenatal clinics } \\
\text { in Ghana (by } 39 \% \text { from } 2001-2010) \text {. } \\
\text { Decreased rate of HIV transmission among } \\
\text { serodiscordant heterosexual couples }{ }^{8} \text {. }\end{array}$ & \\
\hline Viral load & $\begin{array}{l}\text { Reduction in viral failure rates. Optimal viral } \\
\text { suppression was observed as }<20-75 \text { copies } / \mathrm{mL} \text {. } \\
\text { Viral load }<200 \text { copies } / \mathrm{mL} \text { was also observed in } \\
\text { some studies, hence marked as low-level positive } \\
\text { viral load. } \\
\text { viral suppression was generally achieved in } 12-24 \\
\text { weeks }\end{array}$ & $\begin{array}{l}\text { When initial suppression is not } \\
\text { achieved or is lost, rapidly } \\
\text { changing to a new regimen with } \\
\text { at least two active drugs is } \\
\text { required }{ }^{7} \text {. }\end{array}$ \\
\hline CD4 count & $\begin{array}{l}\text { Increased by } 50-150 \text { cells } / \mathrm{mm} 3 \text { of blood (in the } 1^{\text {st }} 3 \\
\text { months of early commencement of ART) in ART } \\
\text { naïve patients }{ }^{7}\end{array}$ & $\begin{array}{l}\text { The CD4 cell count response to } \\
\text { ART varies widely, but a poor } \\
\text { CD4 response is rarely an } \\
\text { indication for modifying a } \\
\text { virologically suppressive ARV } \\
\text { regimen. CD4 Percentage } \\
\text { estimation is a better indicator. }{ }^{7}\end{array}$ \\
\hline
\end{tabular}


Osonuga A , Osonuga OA, Osonuga AA, Osonuga IO

Table II: Toxicity of ARTs

\begin{tabular}{|c|c|c|}
\hline Toxic effect & Implicated ART & Comments \\
\hline GI SYMPTOMS & ${ }_{22}^{\text {Most }}$ ART groups & $\begin{array}{l}\text { Nausea, vomiting, diarrhea are common. Symptoms } \\
\text { may be transient or persist throughout the use of therapy }\end{array}$ \\
\hline $\begin{array}{l}\text { CNS TOXICITY } \\
\text { Nightmares } \\
\text { Peripheral neuropathy } \\
\text { Retinoid toxicity } \\
\text { Fatigue }\end{array}$ & $\begin{array}{l}\text { NVP } \\
\text { d4T } \\
\text { PI } \\
\text { Most ARTs }\end{array}$ & $\begin{array}{l}\text { Usual side effect of NVP was mild as rash. Severe rash } \\
\text { (Steven - Johnson syndrome) however should cause } \\
\text { discontinuation of NVP. }\end{array}$ \\
\hline $\begin{array}{l}\text { METABOLIC } \\
\text { lactic acidosis, } \\
\text { hepatic steatosis, } \\
\text { hyperlactatemia, } \\
\text { hepatotoxicity, } \\
\text { hyperglycemia. }\end{array}$ & $\begin{array}{l}\text { Most NRTIs } \\
\text { Usually with d4T } \\
\text { Most ARTs } \\
\text { Usually with PIs }\end{array}$ & $\begin{array}{l}\text { Lactic acidosis may mimic GI symptoms and hence } \\
\text { should be suspected in patients experiencing GI } \\
\text { symptoms. } \\
10-20 \% \text { of patients experienced hyperlactemia } \\
\text { PIs usually cause elevation of liver enzymes. NVP } \\
\text { induced hepatotoxicity was observed in } 8.9 \% \text { of } \\
\text { patients. }\end{array}$ \\
\hline $\begin{array}{l}\text { LIPODYSTROPHY } \\
\text { fat maldistribution, } \\
\text { Hyperlipidemia, insulin } \\
\text { resistance }\end{array}$ & Most ARTs & $\begin{array}{l}50 \% \text { of patients experience at least one physical } \\
\text { abnormality of lipodystrophy during one year of ART } \\
\text { administration }\end{array}$ \\
\hline $\begin{array}{l}\text { HEMATOTOXICITY } \\
3,7,22 \\
\text { Anemia } \\
\text { Neutropenia } \\
\text { Bleeding episodes in } \\
\text { hemophilia }\end{array}$ & $\begin{array}{l}\text { AZT } \\
\text { 3TC }\end{array}$ & \\
\hline $\begin{array}{l}\text { OSTEOTOXICITY } \\
\text { Osteoporosis and } \\
\text { osteronecrosis }\end{array}$ & Most PIs, NVP & \\
\hline
\end{tabular}

\section{Discussion}

The aim of this research was to review ARTs used in treatment of HIV infection, some of their benefits and toxic effects were also explored.

The CD4 count is the strongest predictor of subsequent disease progression 24 and HIV transmission 7 ,8. Patients with CD4 count $<200$ cells $/ \mathrm{mm} 3$ are at higher risk of opportunistic diseases, non-AIDS morbidity, and death 7 . In clinical trials, lamivudine in combination with zidovudine (known as combivir in Ghana) has been shown to reduce HIV-1 viral load and increase CD4 cell count in a synergistic manner 1,3. This increase in CD4 count in HIV infected patients who begin ART was attributed to reduced rate of viral replication leading to reduced viral load and improved immunological response ${ }^{1,3,7}$. Early onset administration of ART has also shown to improve patient outcome than late onset ${ }^{7,8,25}$.

A reduction in viral load was also observed on administration of ART to ART naïve patients (appen- dix 1). Reduced viremia positively correlates with better clinical outcome and lower viral transmission rates ${ }^{7,25}$. Latent HIIV infection is said to remain because the pool of infected CD4 T-cells established during the earliest stages of acute HIV infection which persists with a long half-life, despite prolonged suppression of plasma viremia by ARTs. ${ }^{7,26}$

Predictors of reduced viremia include high potency of ART, excellent adherence to treatment regimen, low baseline viremia, higher baseline CD4 count (>200 cells/mm3). This is why the WHO advocates for early commencement of ART 7. Slow reduction in viremia despite ART commencement, suggests the presence of transmitted drug-resistant virus. This is observed in up $16 \%$ of ART naïve patients ${ }^{7,24}$.

ART toxicity may be class-specific or peculiar to an ARV (appendix 2)

Lactic acidosis caused by NRTIs results from inhibition of DNA polymerase causing diminished mito- 
A review of some Antiretroviral therapies used in Management of HIV/AIDS in Ghana

chondrial function. Pyruvate is converted to lactate. Impaired oxidation leads to a decrease in fatty acid oxidation causing them to accumulate; stimulating lipogenesis. The excess triglycerides accumulate in the liver, causing hepatic steatosis. Other symptoms include hyperlactemia, fatigue, dyspnea, tachypnea, nausea and weight loss. ${ }^{23}$

Lipodystrophy was first observed in HIV/AIDS patient in1998 23. Patient's age and advanced HIV disease are presently been considered as risk factors. 23,27

Dyslipidemia to levels associated with increased risk of cardiovascular disease occurs in about $70 \%$ of HIV-1 infected patients receiving antiretroviral therapy. It also increases the risk of cardiovascular diseases and insulin resistance leading to hyperglycemia usually without frank diabetes mellitus. ${ }^{23,28}$

Hepatotoxicity associated with most of the antiretroviral agents is possibly due to interaction with liver enzymes during metabolism 23. Most studies implicated PIs as more usual causes of hepatotoxicity. The rate of severe ART induced hepatotoxicity among patients with hepatitis $\mathrm{C}$ infection is higher than those without the infection ${ }^{7,23,29}$.
Antiretroviral associated lactic acidosis, phosphate compensation for anion gap30, inhibition of new bone formation by stimulating osteoclast activity or inhibiting osteoblast activity 31, metabolizing by cytochrome $\mathrm{P} 450$ enzymes, the oxygenase that activates vitamin D 23 have been suggested as causes of ART induced osteoporosis

Hematotoxicity of ARTs especially with the use of NRTIs like AZT can cause life threatening anemia, possibly due to bone marrow suppression. ${ }^{2}$

\section{Conclusion}

Although the therapeutic goals of ART include achieving and maintaining viral suppression and improving patients' immune function, it is important to select a regimen that not is only effective but also is safe. This requires consideration of not only the toxicity potential of an ARV regimen but also an individual patient's underlying conditions (e.g. successful treatment of hepatitis $C$ in dually infected patients before the introduction of PI-containing antiretroviral therapy), concomitant medications, and history of drug intolerance.

Pretreatment genotypic resistance testing is also advised as guide to selecting the most beneficial initial ARV regimen for a patient.

\section{References}

1. Osonuga IO, Osonuga OA, Osonuga AA. Gonadtoxicity evaluation of oral administration of Zidolam in male albino rats. Macedonian Journal of Medical Sciences 2010; 3(4): 378-382

2. Ghana Health Service. Guidelines for the clinical management and TB and HIV co-infection in Ghana. 20071 - 51

3. Osonuga OA, Osonuga IO, Osonuga A. Hemtological changes with Zidolam. Asian Journal of Medical Sciences. 2010; 1(1): 41-44

4. WHO. Antiretroviral therapy. website: http://www.who.int/hiv/topics/treatment/en/index. html

5. Delaney M. History of HAART - the true story of how effective multi-drug therapy was developed for treatment of HIV disease. Retrovirology 2006; 3(Suppl 1): S6 http://dx.doi.org/10.1186/17424690-3-S1-S6PMCid:1716971

6. AVART. Introduction to HIV and AIDS drug treat- ment. Website: http://www.avert.org/treatment.htm

7. WHO. Guidelines for the Use of Antiretroviral Agents in HIV-1-Infected Adults and Adolescents

8. WHO. Global HIV/AIDS response: Epidemic update and health sector progress towards Universal Access.

9. Ministry of Health. Guideline for antiretroviral therapy in Ghana 2002. Available from website: http://collections.infocollections.org/whocountry/e n/d/Js6867e/4.2.html. accessed 2011

10. Nana Ayisi. Sex viruses and grief: a deadly combination that poses the greatest threat to Human Health in the 21th century.

11 Jawetz. Medical Microbiology. Lange publishers. 24th Edition. 2007

12. Katzung BG. Antiviral agents in Basic and Clinical Pharmacology. McGrawHill companies (Singapore). 10th edition 2007. Pg 790.

13. Tripathi KD. Antiviral Drugs in Essentials of Medical Pharmacology. 5th Edition. Jaypee pub- 
Osonuga A, Osonuga OA, Osonuga AA, Osonuga IO

lishers. 3003. Pg 725.

14. WHO: HIV/AIDS treatment and care. Clinical protocols for the WHO European Region. Online (2007) Available from URL:http://www.euro.who.int/_data/assets/pdf_fil e/0004/78106/E90840.pdf

15. Antiretroviral therapy. Available from URL:http://www.wikipedia.com

16. AVERT: AIDS, drug prices and Generic drugs. Available online from URL:http://www.avert.com

17. Kalayjian RC, Franceschini N, Gupta SK, et al. Suppression of HIV-1 replication by antiretroviral therapy improves renal function in persons with low CD4 cell counts and chronic kidney disease. AIDS2008;22(4):481-487.http://dx.doi. org/10.1097/QAD.0b013e3282f4706dPMid:1830 1060

18. Molina JM, Andrade-Villanueva J, Echevarria J, et al. Once-daily atazanavir/ritonavir compared with twice-daily lopinavir/ritonavir, each in combination with tenofovir and emtricitabine, for management of antiretroviral-naive HIV-1-infected patients: 96-week efficacy and safety results of the CASTLE study. J Acquir Immune Defic Syndr 2010;53(3):323-332http://dx.doi.org/10.1097/ QAI.0b013e3181c990bfPMid:20032785

19. McComsey G, Smith K, Patel P, et al. Similar reductions in markers of inflammation and endothelial activation after initiation of abacavir/lamivudine or tenofovir/emtricitabine: The HEAT Study. Paper presented at: 16th Conference on Retroviruses and Opportunistic Infections; 2009; Montreal, Canada.

20. Smith C. Factors associated with specific causes of death amongst HIV-positive individuals in the D:A:D Study. AIDS 2010;24(10):1537-1548. PMid:20453631

21. Riddler SA, Li X, Otvos J, et al. Antiretroviral therapy is associated with an atherogenic lipoprotein phenotype among HIV-1-infected men in the Multicenter AIDS Cohort Study. J Acquir Immune Defic Syndr 2008;48(3):281-288. http://dx.doi.org/10.1097/QAI.0b013e31817bbbf0 PMid:18545156

22. El-Sadr WM, Lundgren JD, Neaton JD, et al. CD4+ count-guided interruption of antiretroviral treatment. $N$ Engl J Med 2006;355(22):2283-2296. http://dx.doi.org/10.1056/NEJMoa062360 PMid:17135583

23. Montessori V, Press N, Harris M, Akagi L and
Montaner JSG. Adverse effects of antiretroviral therapy for HIV infection. CMAJ

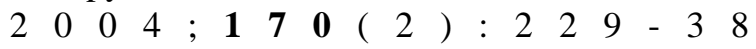
PMid:14734438 PMCid:315530

24. Dinoso JB, Kim SY, Wiegand AM, et al. Treatment intensification does not reduce residual HIV-1 viremia in patients on highly active antiretroviral therapy. Proc Natl Acad Sci $U$ S A. $2009 ; 106$ ( 23 ) : $9403-9408$ http://dx.doi.org/10.1073/pnas.0903107106 PMid:19470482 PMCid:2685743

25. Kitahata MM, Gange SJ, Abraham AG et al. The effect of early versus deffered antiretroviral therapy for HIV on survival. $N$ Engl $J$ Med 2009; 360(18):

1815-1826. http://dx.doi.org/10.1056/NEJMoa0807252 PMid:19339714 PMCid:2854555

26. Chun TW, Engel D, Berrey MM, et al. Early establishment of a pool of latently infected, resting CD4(+) T cells during primary HIV-1 infection. Proc Natl Acad Sci U S A 1998;95(15):8869-8873 http://dx.doi.org/10.1073/pnas.95.15.8869

27. Martinez E, Mocroft A, Garcia-Viejo MA, PerezCuevas JB, Blanco JL, Mallolas et al. Risk of lipodystrophy in HIV-1-infected patients treated with protease inhibitors: a prospective cohort study. Lancet 2001;357(9256):592-8 http://dx.doi.org/10.1016/S0140-6736(00)04056-3

28. Friis-Moller N, Weber R, D’Arminio Monforte A, El-Sadr W, Reiss P, Dabis F, et al. Exposure to HAART is associated with an increased risk of myocardial infarction: the DAD Study [abstract 130]. 10th Conference on Retroviruses and Opportunistic Infections, 2003 Feb 10-14; Boston

29. Brinker M, Wit FNM, Jurriaans S, Weel J, et al. Hepatitis B and C virus co-infection and the risk for hepatotoxicity of highly active antiretroviral therapy in HIV-1 infection. AIDS 2000;14(18):2895-902. http://dx.doi.org/10.1097/ 00002030-200012220-00011PMid:11153671

30. Carr A, Eisman JA, Miller J, Cooper DA. Lactic acidemia is associated with spinal osteopenia in HIV-infected men [abstract 631]. 8th Conference on Retroviruses and Opportunistic Infections; 2001 Feb 4-8; Chicago.

31.Wang M, Teitelbaum SL, Tebas P, Powderly WG, Ross FP. Indinavir inhibits bone formation while ritonavir inhibits osteoclast differentiation and function [abstract 541]. 8th Conference on Retroviruses and Opportunistic Infections; 2001 Feb 4-8; Chicago. 